\title{
The Role of Multidetector Computed Tomography in the Early Diagnosis of Invasive Pulmonary Aspergillosis in Patients with Febrile Neutropenia Undergoing Hematopoietic Stem Cell Transplantation
}

\author{
Hematopoetik Kök Hücre Transplantasyonu Sonrası Gelişen Febril \\ Nötropenide İnvaziv Pulmoner Aspergillozis Erken Tanısında \\ Multidedektör Bilgisayarl Tomografinin Rolü
}

Nazan Çiledağ ${ }^{1}$, Kemal Arda ${ }^{1}$, Bilgin Kadri Arıbaş ${ }^{1}$, Ali Irfan Emre Tekgündüz ${ }^{2}$, Fevzi Altuntaş ${ }^{2}$

${ }^{1}$ Ankara Oncology Education and Research Hospital, Department of Radiology, Ankara, Turkey

${ }^{2}$ Ankara Oncology Education and Research Hospital, Department of Hematology and BMT Unit, Ankara, Turkey

\begin{abstract}
Objective: To evaluate vessel involvement and the role of multidetector computed tomography (MDCT) in the early diagnosis of invasive pulmonary aspergillosis (IPA) in patients with febrile neutropenia and antibiotic-resistant fever undergoing autologous bone morrow transplantation.
\end{abstract}

Material and Methods: In all, 74 pulmonary MDCT examinations in 37 consecutive hematopoietic stem cell transplantation patients with febrile neutropenia and clinically suspected IPA were retrospectively evaluated.

Results: Diagnosis of IPA was based on Fungal Infections Cooperative Group, and National Institute of Allergy and Infectious Diseases Mycoses Study Consensus Group criteria. In all, 0, 14, and 11 patients were diagnosed as proven, probable, and possible IPA, respectively. Among the 25 patients accepted as probable and possible IPA, all had pulmonary MDCT findings consistent with IPA. The remaining 12 patients were accepted as having fever of unknown origin (FUO) and had patent vessels based on MDCT findings.

In the patients with probable and possible IPA, 72 focal pulmonary lesions were observed; in 41 of the $72(57 \%)$ lesions vascular occlusion was noted and the CT halo sign was observed in 25 of these 41 (61\%) lesions. Resolution of fever occurred following antifungal therapy in $19(76 \%)$ of the 25 patients with probable and possible IPA. In all, 6 (25\%) of the patients diagnosed as IPA died during follow-up. Transplant-related mortality $100 \mathrm{~d}$ post transplant in patients with IPA and FUO was $24 \%$ and $0 \%$, respectively.

Conclusion: In conclusion, MDCT has a potential role in the early diagnosis of IPA via detection of vessel occlusion.

Key Words: Multidetector computed tomography, Invasive pulmonary aspergillosis, Febrile neutropenia, Hematopoietic stem cell transplantation

Address for Correspondence: Nazan ÇİLEDAĞ, M.D.,

Ankara Onkoloji Eğitim ve Araştırma Hastanesi, Radyoloji Bölümü, Demetevler, Ankara, Turkey

Phone: + 9031233609 09-1390 E-mail: drnazangokbayrak@yahoo.com.tr 


\section{Özet}

Amaç: Otolog kemik iliği transplantasyonlu febril nötropenik ve antibiyotiğe dirençli orjini bilinmeyen hastalarda, vasküler tutulum ve invaziv pulmoner aspergillozis (IPA) erken tanısında multidedektör bilgisayarlı tomografi (MDBT)'nin rolünü değerlendirmek amaçlanmıştır.

Gereç ve Yöntemler: Orjini bilinmeyen geniş spektrumlu antibiyotiğe dirençli ateşi olan, İPA şüphesi bulunan 37 olgunun 74 pulmoner MDBT incelemesi retrospektif değerlendirildi.

Bulgular: İnvaziv pulmoner aspergillozis tanısı mikrobiyolojik, radyolojik bulgularla birlikte host faktörleri değerlendirilerek konuldu. 25 olguya EORTC/MSG kriterlerine göre sırasılyla 0, 14, 11 olguya kanıtlanmış, olası, muhtemel İPA tanısı konuldu. Olası veya muhtemel İPA tanısı konan 25 olgunun MDBT'sinde IPA ile uyumlu bulgular görüldü. Ne kültürde üreme, ne de radyolojik pozitif bulgu saptanmayan 12 olguda (nedeni bilinmeyen ateş) MDBT'de vasküler yapılar patent idi. Olası/muhtemel İPA tanısı konan 25 olguda total 72 fokal pulmoner lezyon saptandı. 72 lezyonun 41'inde (\%57) MDBT'de İPA'yı destekleyen vasküler oklüzyon saptandı. Olası/muhtemel İPA tanısı konan 25 olgunun 19'unda (\%76) klinik düzelme, ateşin düşüşü gözlendi. İnvaziv pulmoner aspergillozis tanısı konan 6 olgu takipler sırasında kaybedildi. İnvaziv pulmoner aspergillozis ve nedeni binmeyen ateş saptanan olgularda 100 günlük takip sonrasında transplant ilişkili mortalite oranı sırasıyla \%24 ve \%0 idi.

Sonuç: Sonuç olarak, vasküler tutulumu gösterebilmesi nedeniyle MDBT'nin İPA tanısında potansiyel rolü olduğu kanisina varildı.

Anahtar Sözcükler: Multidedektör bilgisayarlı tomografi, İnvaziv pulmoner aspergillozis, Febril nötropeni, Hematopoetik kök hücre transplantasyonu

\section{Introduction}

Fungal infection is one of the primary causes of post hematopoietic stem cell transplantation (HSCT) mortality and morbidity, despite routine prophylaxis for common pathogenic organisms and empiric treatment of febrile episodes during the early neutropenic period [1,2]. In the era of routine fluconazole prophylaxis for high-risk populations, molds-especially Aspergillus species-became the most common and life-threatening pathogenic organism, leading to fungal pneumonia in febrile neutropenic patients and causing 90\% of such infections [3,4]. Early and accurate diagnosis of invasive pulmonary aspergillosis (IPA) in immunocompromised patients is the ultimate method of lowering the mortality and morbidity rates associated with the pathogen [5]. A 10-d delay in initiation of antifungal therapy nearly doubles the IPA-related mortality rate [5].

High-resolution CT visualization of the halo sign-indicative of a hemorrhagic pulmonary nodule-is an early sign of IPA with high sensitivity and specificity [6]; however, differential diagnosis of the halo sign is quite complex, as it may be observed as a result of infection with other microorganisms [(Candida spp., mucormycosis, cryptococcosis, cytomegalovirus (CMV), herpes simplex virus (HSV)] and other diseases, including Wegener granulomatosis, pulmonary metastases of hypervascular tumors, and Kaposi's sarcoma $[7,8]$. Pathologic examination of nodules with the halo sign showed that the halo around a central fungal lesion corresponded to a nodule surrounded by a rim of coagulation necrosis due to the vascular invasion that causes thrombotic occlusion and ischemic necrosis [9]. Due to limitations of these radiological findings, a few recent studies evaluated the role of multidetector computed tomographic (MDCT) angiography in the early and accurate diagnosis of IPA [10].

The primary aim of the present study was to evaluate vessel involvement and the role of multidetector computed tomography (MDCT) in the early diagnosis of invasive IPA in patients with febrile neutropenia and antibiotic-resistant fever undergoing HSCT.

\section{Material and Methods}

In all, 37 consecutive HSCT patients (24 male and 13 female) with a mean age of $41 \pm 19$ years (range: 4-68 years) and clinically suspected IPA due to febrile neutropenia and broad-spectrum antibiotic-resistant fever of unknown origin that underwent 74 pulmonary MDCT examinations between March 2009 and June 2010 were retrospectively evaluated. In total, 27 of the patients (73\%) had acute leukemia, 2 (5\%) had chronic leukemia, 7 (19\%) had lymphoma, and 1 (3\%) had multiple myeloma. The patients with acute and chronic leukemia were treated with allogeneic HSCT from 6/6 HLA-matched related donors. The other patients underwent autologous peripheral stem cell transplantation and were neutropenic 
(absolute neutrophil count $<500 \mathrm{~mm}^{-3}$ for at least $11 \mathrm{~d}$ ) following myeloablative conditioning. The conditioning regimen in the patients with acute/chronic leukemia was $\mathrm{TBI} / \mathrm{Cy}$ or Bu/Cy, whereas patients with lymphoma and myeloma received BEAM and MEL200, respectively.

All the HSCT patients received levofloxacin, fluconazole, acyclovir, and trimethoprim-sulfamethoxazole as primary prophylaxis. Allogeneic HSCT recipients received cyclosporin and short-term methotrexate for prophylaxis of graft versus host disease. According to our hematology/ stem cell transplantation protocol, febrile neutropenic patients that were unresponsive to broad-spectrum antibiotics (imipenem or meropenem) for $72 \mathrm{~h}$ were evaluated for opportunistic fungal pathogens. We adapted a similar (not the same) pre-emptive strategy pioneered by Maertens et al. [11)—serum galactomannan (GM) assay (twice weekly) and thoracic MDCT. Patients that had hemodynamic instability and/or 2 consecutive positive serum GM assays (ELISA: optical density $\geq 0.5$ ), and/ or thoracic MDCT findings suggesting IPA (pulmonary nodule irrespective of the halo sign, air crescent sign, or cavitation) supported by mycological evidence of molds (presence of fungal elements indicating molds in sputum/ bronchoalveolar lavage fluid or positive culture for molds) were treated with antifungal agents. Patients with mycological evidence of Aspergillus spp. received voriconazole; all others were treated with caspofungin.

Persistent or relapsing fever was not considered an indication for antifungal therapy. Once initiated, antifungal therapy was continued for 6 weeks. In patients that were unresponsive to pre-emptive antifungal treatment, MDCT was repeated; hence, it was performed more than once in some patients. Patients with renal insufficiency were excluded from the study. The study protocol was approved by Ankara oncology hospital review board and written informed consent was received from all patients. The diagnosis of IPA was based on evaluation of host factors, together with mycological and radiological findings, according to the international consensus guidelines [12]. Due to safety concerns, no patient underwent transbronchial/percutaneous lung biopsy or needle aspiration of radiologically suspected lesions, allowing histopathologic or cytopathologic examination.

Pulmonary CT was performed caudocranially with an MDCT scanner (GE Medical Systems, Milwaukee, WI, USA) after administration of $100 \mathrm{~mL}$ of intravenous contrast media (ioversol, $350 \mathrm{mg} \mathrm{mL}^{-1}$ organically bound iodine, Optiray, Covidien, Tyco, USA) at a rate of $4 \mathrm{~mL} \mathrm{~s}^{-1}$. MDCT was performed with 20-s delay during breath-hold.
Scanning parameters were as follows: slice thickness: 1.25 $\mathrm{mm}$; helical rotation time: $0.5 \mathrm{~s}$; collimation: $1.25 \mathrm{~mm}$; voltage: $120 \mathrm{kV}$; current: $120 \mathrm{mAs}$. After completion of CT scanning the reconstruction process was applied and multiplanar reconstructed (sagittal, coronal, and oblique planes) images were created. Axial images were evaluated for nodules, cavitation, and the halo sign, and then any focal pulmonary lesions observed were evaluated for vascular involvement-defined as an interruption of the vessel at the border of the focal nodular lesion in multiplanar reconstructed images-and evaluated based on the consensus of 2 radiologists. Results were correlated with clinical follow-up data, including serum galactomannan values and CT findings during a median follow-up of $93 \mathrm{~d}$ (range: 10-220 d).

\section{Statistical Analysis}

Statistical analysis was performed using SPSS v.13.0. Categorical variables are presented as numbers and percentages, and continuous variables are presented as mean \pm SD or median.

\section{Results}

According to EORTC/MSG criteria, 0, 14, and 11 patients were diagnosed as proven, probable, and possible IPA, respectively. Sputum culture in 2 patients showed infection with Aspergillus spp. Among the 14 patients with probable IPA, 2 had Aspergillus-positive culture and 12 patients had 2 consecutive positive GM assays. These 14 patients also had pulmonary CT findings indicative of IPA. In all, 11 of the 37 patients that had both host and radiological findings suggesting IPA did not have culture or non-culture-based test results consistent with IPA (possible IPA). In the remaining 12 patients the diagnosis of IPA was excluded by any level of evidence and these patients were regarded as having fever of unknown origin

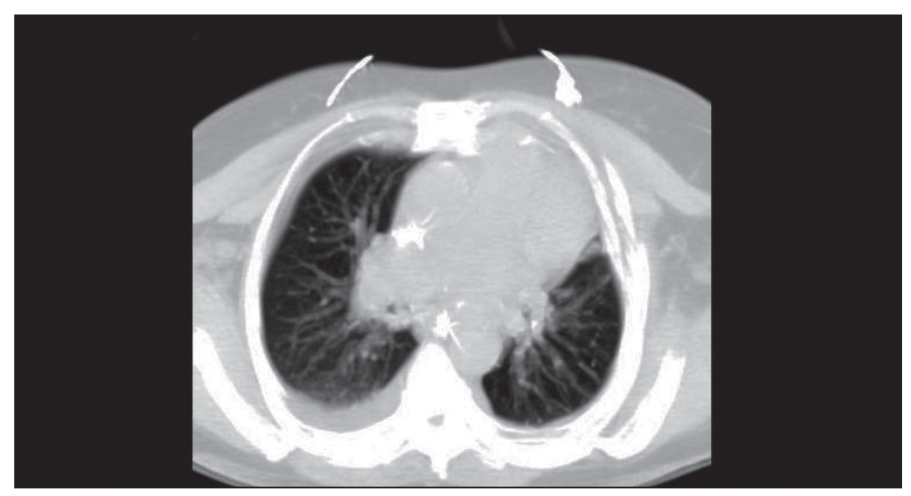

Figure 1: Contrast-enhanced MDCT axial plane maximum intensity projection image shows patent vessels. 
(FUO). All the patients with FUO had patent vessels, based on MDCT (Figure 1). Among the patients with FUO, 3 had consolidation, with strong and patent vessels in and around the consolidation, whereas the other 9 patients had no pathology based on MDCT. On the other hand, $18(72 \%)$ of the patients that were diagnosed as probable and possible IPA had abnormal MDCT findings (Table 1).

In the patients with probable and possible IPA 72 focal pulmonary lesions were detected via MDCT; the lesions ranged from 6 to $40 \mathrm{~mm}$ (mean: $1.7 \pm 0.6 \mathrm{~mm}$ ). In 41 of the 72 (57\%) lesions vascular occlusion was noted, which was defined as an interruption of a vessel at the border of a focal lesion (without depiction of the vessel) or peripheral to the lesion (Figure 2A,B). The CT halo sign was noted in 25 of the $41(61 \%)$ lesions. In total, 9 cavitary pulmonary nodules with a surrounding halo of ground-glass attenuation were detected using MDCT. Clinical improvement and resolution of fever was achieved following antifungal therapy in 19 (76\%) of the 25 patients with probable and possible IPA. In patients with clinical deterioration, there was also progression of radiological findings based on
MDCT. In all, 6 (25\%) patients that were diagnosed as IPA died during follow-up. In 3 of the 12 patients with normal MDCT findings and persistent fever MDTC was repeated and the results were again normal; there were no clinical or laboratory findings supporting the diagnosis of IPA among them. Transplant-related mortality (TRM) 100 $\mathrm{d}$ post transplant in the patients with IPA and FUO was $24 \%$ and $0 \%$, respectively.

\section{Discussion}

IPA is one of the most serious pulmonary complications of HSCT. The incidence of IPA varies widely according to study population. The risk of proven and probable IPA among autologous transplant recipients is quite low (0.5\%$1 \%$ ), as compared to patients undergoing allogeneic HSCT or those treated with induction chemotherapy for acute leukemia (3\%-7\%) [13-15]. Although rare, IPA is associated with high mortality and morbidity rates following HSCT, especially during the early neutropenic period $[10,16]$. The mortality rate due to IPA when treated with appropriate antifungal therapy ranges from $30 \%$ to $80 \%$ [17]. Early

Table 1: MDCt Findings and Clinical Outcomes in the Study Group

\begin{tabular}{l|c|c|c|}
\hline Diagnosis $^{*}$ & $\mathbf{n}$ & $\begin{array}{c}\text { Vascular occlusion } \\
\mathbf{n}(\%)\end{array}$ & $\begin{array}{c}\text { Mortality } \\
\mathbf{n}(\%)\end{array}$ \\
\hline Proven IPA & 0 & NA & NA \\
\hline Probable IPA & 14 & $12(86 \%)$ & $4(29 \%)$ \\
\hline Possible IPA & 11 & $6(55 \%)$ & $2(18 \%)$ \\
\hline FUO & 12 & $0(0 \%)$ & $0(0 \%)$ \\
\hline
\end{tabular}

NA: Not applicable. "According to EORTC/MSG criteria. *A According to MDCT findings.

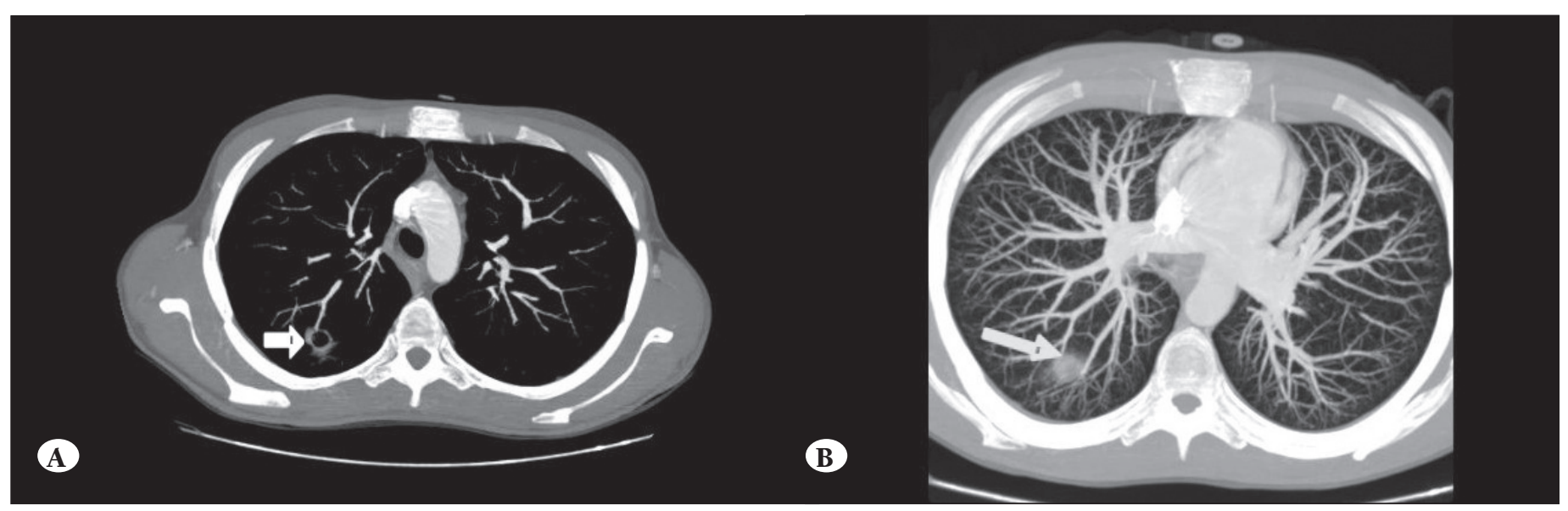

Figure 2: A 24-year-old male with acute myeloid leukemia. (A) Contrast-enhanced MDCT scan of the chest obtained with lung window settings shows a cavitary nodular lesion (arrow) with a peripheral halo sign. (B) Contrast-enhanced MDCT axial plane maximum intensity projection image shows interruption of the peripheral segmental pulmonary artery (arrow) at level of the pulmonary nodule. 
and accurate diagnosis of IPA is critical because initiation of specific antifungal therapy decreases the mortality rate from $80 \%$ to $30 \%$ [6]. In the present study MDCT findings in 37 HSCT patients with neutropenia and antibioticresistant FUO, and clinically suspected IPA were retrospectively evaluated via in order to detect the existence of focal pulmonary lesions, the halo sign, and vascular occlusion. Due to severe thrombocytopenia, poor clinical condition, and high risk of complications associated with invasive diagnostic procedures, diagnoses were based on clinical, microbiological, and radiological findings.

A pulmonary nodule with the halo sign observed with high-resolution CT is an important and early sign of IPA; however, the halo sign is a non-specific imaging finding that may be observed in other diseases $[7,8]$. During the last 10 years technological progress in medical imaging has resulted in MDCT, which has many advantages over singledetector helical CT, including shorter acquisition time, greater anatomic coverage, and superior image resolution during a single breath-hold, facilitating improved patient comfort and excellent three dimensional (3D) reconstructions. All these factors substantially increase diagnostic accuracy via state-of-the-art image quality. 3D isotropic volume imaging is possible with MDCT and provides excellent anatomical imaging of the thorax, thereby significantly increasing the diagnostic yield. MDCT has resulted in a paradigm shift in vascular imaging-from conventional catheter angiography to MDCT angiography-as MDCT provides image quality that equals or surpasses that of conventional angiography.

Recent advances in 3D volume rendering enable detection of occlusion of peripheral vessels at the border of a suspicious fungal lesion. Hypothetically, vasculitic change in peripheral vessels can cause occlusion of peripheral vessels. Vessel occlusion secondary to vascular invasion by IPA results in edema, which is referred to as the CT-halo sign. Sonnet el al. reported that direct detection of vessel occlusion, which was defined as an interruption of a vessel at the border of a focal nodular pulmonary lesion, is an earlier finding than the halo sign and may be useful in the early diagnoses of IPA [10]. In the present study only $61 \%$ of the patients with vascular occlusion around the pulmonary nodules had the halo sign, which is in agreement with the findings of Sonnet el al. [10], and therefore it seems logical to conclude that MDCT could be a valuable tool for the early diagnosis of IPA. As the present study's cohort consisted of only 37 patients, it is impossible to definitively state the value of MDCT in the diagnosis of IPA based on the present findings.
According to the recently published EORTC/MSG criteria, the rate of proven/probable IPA in the present study was $38 \%$, which is much higher than expected, and this discrepancy has several possible causes. In order to focus on a population with a high risk for IPA we included only patients with defined host factors based on EORTC/ MSG criteria. In addition to the allogeneic transplant recipients, all 8 patients that were treated with autologous HSCT had profound neutropenia for at least $11 \mathrm{~d}$. Autologous HSCT patients that did not fulfill EORTC/ MSG host criteria were not included in the study. Additionally, there are some drawbacks associated with the use of serum GM-ELISA assay for the detection of IPA. Recent data show that the positive predictive value (58\%-73\%) of the test is not optimal [15]. In order to increase the sensitivity and safety of the pre-emptive approach we used a rather low threshold for positivity (optical density $\geq 0.5$ ). Moreover, a vast majority of the patients $(\mathrm{n}=29$ [78\%]) were treated with a conditioning regimen that included high-dose cyclophosphamide, which can cause false positive GM assay results [18]. In consideration of the fact that none of the present study's patients had proven IPA and all 14 patients with probable IPA had 2 consecutive positive GM assays, the high rate of IPA observed may be an overestimation of the real picture.

The diagnosis of IPA in the present study was based on evaluation of host factors, together with mycological and radiological findings, according to the international consensus guidelines [12]. The major limitation of the present study is the lack of histopathologic diagnosis of IPA, which was not performed due to safety concerns. In conclusion, MDCT shows promise as an imaging technique for accurate and early detection of vessel occlusion in HSCT patients with suspected IPA; however, additional research with larger patient populations is needed to further establish its accuracy.

\section{Conflict of Interest Statement}

The authors of this paper have no conflicts of interest, including specific financial interests, relationships, and/ or affiliations relevant to the subject matter or materials included.

\section{References}

1. Soubani AO, Miller KB, Hassoun PM: Pulmonary complications of bone marrow transplantation. Chest 1996; 109: 1066-1077

2. Krowka MJ, Rosenow EC, 3rd, Hoagland HC: Pulmonary complications of bone marrow transplantation. Chest 1985; 87: $237-246$ 
3. Breuer R, Lossos IS, Berkman N, Or R: Pulmonary complications of bone marrow transplantation. Respir Med 1993; 87: $571-579$

4. Wah TM, Moss HA, Robertson RJ, Barnard DL: Pulmonary complications following bone marrow transplantation. Br J Radiol 2003; 76: 373-379

5. Heussel CP, Kauczor HU, Heussel, Fischer B, Mildenberger P, Thelen M: Early detection of pneumonia in febrile neutropenic patients: Use of thinsection CT. AJR 1997; 169: 1347-1353

6. Blum U, Windfuhr M, Buitrago-Tellez C, Sigmund G, Herbst EW, Langer M: Invasive pulmonary aspergillosis: MRI, CT, and plain radiographic findings and their contribution for early diagnosis. Chest 1994; 106: 1156-1161

7. Primack SL, Hartman TE, Lee KS, Müller NL: Pulmonary nodules and the CT halo sign. Radiology 1994; 190: 513-515

8. Zinck SE, Leung AN, Frost M, Berry GJ, Müller NL: Pulmonary cryptococcosis: CT and pathologic findings. J Comput Assist Tomogr 2002; 26: 330-334

9. Hruban RH, Meziane MA, Zerhouni EA, Wheeler PS, Dumler JS, Hutchins GM: Radiologic-pathologic correlation of the CT halo sign in invasive pulmonary aspergillosis: Case report. J Comput Assist Tomogr 1987; 11: 534-536

10. Sonnet S, Buitrago-Tellez CH, Tamm M, Christen S, Steinbrich W: Direct Detection of Angioinvasive Pulmonary Aspergillosis in Immunosuppressed Patients: Preliminary Results with High-Resolution 16-MDCT Angiography. AJR Am j Roentgenol 2005; 185: 746-751

11. Maertens J, Theunissen K, Verhoef G, Verschakelen J, Lagrou K, Verbeken E, Wilmer A, Verhaegen J, Boogaerts M, Van Eldere J: Galactomannan and computed tomography-based preemptive antifungal therapy in neutropenic patients at high risk for invasive fungal infection: A prospective feasibility study. Clin Infect Dis 2005; 41: 1242-1250
12. De Pauw B, Walsh TJ, Donnelly JP, Stevens DA, Edwards JE, Calandra T, Pappas PG, Maertens J, Lortholary O, Kauffman CA, Denning DW, Patterson TF, Maschmeyer G, Bille J, Dismukes WE, Herbrecht R, Hope WW, Kibbler CC, Kullberg BJ, Marr KA, Muñoz P, Odds FC, Perfect JR, Restrepo A, Ruhnke M, Segal BH, Sobel JD, Sorrell TC, Viscoli C, Wingard JR, Zaoutis T, Bennett JE; Fungal Infections Cooperative Group; National Institute of Allergy and Infectious Diseases Mycoses Study Group (EORTC/MSG) Consensus Group: Revised definitions of invasive fungal disease from the European Organization for Research and Treatment of Cancer/Invasive. Clin Infect Dis 2008; 46: 1813-1821

13. Jantunen E, Salonen J, Juvonen E, Koivunen E, Siitonen T, Lehtinen T, Kuittinen O, Leppä S, Anttila VJ, Itälä M, Wiklund T, Remes K, Nousiainen T: Invasive fungal infections in autologous stem cell transplant recipients: A nationwide study of 1188 transplanted patients. Eur J Haematol 2004; 73: 174-178

14. Morgan J, Wannemuehler KA, Marr KA, Hadley S, Kontoyiannis DP, Walsh TJ, Fridkin SK, Pappas PG, Warnock DW: Incidence of invasive aspergillosis following hematopoietic stem cell and solid organ transplantation: Interim results of a prospective multicenter surveillance program. Med Mycol 2005; 43: 49-58

15. British Committee for Standards in Haematology. Guidelines on the management of invasive fungal infections during therapy for haematological malignancy. (http://www.bcshguidelines.com/documents/fungal_infection_bcsh_2008. pdf; accessed on November 30; 2010)

16. Jantunen E, Ruutu P, Piilonen A, Volin L, Parkkali T, Ruutu $\mathrm{T}$ : Treatment and outcome of invasive Aspergillus infections in allogeneic BMT recipients. Bone Marrow Transplant 2000; 26: 759-762

17. Lin SJ, Schranz J, Teutsch SM: Aspergillosis case-fatality rate: systematic review of the literature. Clin Infect Dis 2001; 32: 358-366

18. Hashiguchi K, Niki Y, Soejima R: Cyclophosphomide induces false-positive results in detection of aspergillus antigen in urine. Chest 1994; 105: 975-976 